\title{
ASUHAN KEPERAWATAN KANKER NASOFARING DENGAN FOKUS STUDI PENATALAKSANAAN NYERI DI RSUD TIDAR KOTA MAGELANG
}

\author{
Sri Rahayu \\ Jurusan Keperawatan Poltekkes Kemenkes Semarang \\ Prodi D III Keperawatan Magelang \\ E-mail :srahayu0397@gmail.com
}

\begin{abstract}
Cancer / nasopharyngeal carcinoma (NPC) is a malignant cancer in the head and neck. This cancer is located in the nasopharynx, behind the nose. NPC including five large malignant tumors. Ebstein Barr is one of the triggers of this carcinoma. Most NPC patients come to the clinic for treatment at an advanced stage. The purpose of writing is to discuss and examine the application of nursing care with a focus on pain studies on clients with nasopharyngeal cancer. The method used by the writer is descriptive by managing one client who has nasopharyngeal cancer. The results of the study were obtained as long as $2 \times 24$ hours of nursing care was provided, the pain problem was resolved in accordance with the established criteria with the results of the implementation carried out in accordance with the client's developmental response. During the evaluation of nursing care that has been given for 2 consecutive days there is a nursing problem that pain can be resolved.
\end{abstract}

\section{Keywords : Nasopharyngeal Cancer, Pain, Nursing Care}

Abstrak : Kanker / karsinoma nasofaring (KNF) adalah kanker ganas di kepala dan leher. Kanker ini terletak di nasofaring, di belakang hidung. KNF termasuk lima besar tumor ganas. Ebstein Barr adalah salah satu pemicu karsinoma ini. Kebanyakan penderita KNF datang berobat di klinik sudah stadium lanjut. Tujuan dari penulisan adalah untuk membahas dan mengkaji penerapan asuhan keperawatan dengan fokus studi nyeri pada klien dengan kanker nasofaring. Metode yang digunakan penulis adalah deskriptif dengan mengelola satu klien yang menderita kanker nasofaring. Hasil dari penelitian didapatkan selama diberikan asuhan keperawatan 2x24 jam masalah nyeri teratasi sesuai dengan kriteria yang ditetapkan dengan hasil implementasi yang dilakukan sesuai dengan respon perkembangan klien. Kesimpulan pada saat dilakukan evaluasi asuhan keperawatan yang telah diberikan selama 2 hari berturut-turut terdapat 4 masalah keperawatan yang teratasi.

Kata Kunci : Kanker Nasofaring, Nyeri, Asuhan Keperawatan

\section{PENDAHULUAN}

Kanker nasofaring (KNF) merupakan salah satu keganasan pada kepala dan leher yang paling banyak dijumpai terutama pada pria usia produktif pada sebagian besar populasi di Asia Tenggara, dan Afrika (Damayanti, Afiati, Hasan \& Hernowo 2015).

Kanker nasofaring adalah tumor ganas yang berasal dari sel epitel nasofaring (Hasibuan, 2010).

Kanker nasofaring stadium awal (stadium I dan II) bersifat radioresponsif sehingga radioterapi sering digunakan sebagai terapi kanker nasofaring karena menunjukkan keefektifan yang tinggi terhadap kematian sel kanker nasofaring (Nasir \& Muhith, 2010).

Kanker nasofaring (KNF) merupakan salah satu penyakit yang ditimbulkan oleh interaksi antara virus Epstein Barr, risiko genetik dan paparan lingkungan, sehingga bisa dikatakan bahwa etiologi KNF bersifat multifaktorial. Faktor risiko diantaranya faktor lingkungan, genetik, gaya hidup dan okupasi. Badan Registrasi Kanker Indonesia menyatakan bahwa Kanker kepala leher menempati urutan keempat dari sepuluh besar keganasan pada pria dan wanita, serta urutan kedua tersering dari pria. Karsinoma Nasofaring (KNF) merupakan tumor ganas yang paling banyak dijumpai diantara tumor ganas THT di Indonesia, dimana KNF termasuk dalam lima besartumor ganas, dengan frekuensi tertinggi (bersama tumor ganas serviks uteri, tumor payudara, tumor getah bening dan tumor kulit), sedangkan didaerah kepala dan leher menduduki tempat pertama (KNF mendapat persentase hampir $60 \%$ dari tumor di daerah kepala dan leher, diikuti tumor ganas hidung dan sinus paranasal $18 \%$, laring $16 \%$, dan tumor ganas rongga mulut, tonsil, hipofaring dalam persentase rendah.

Distribusi penyakit ini paling banyak dijumpai pada ras Mongol, di samping Mediteranian, dan beberapa ras di Afrika di bagian Utara. Di Hongkong tercatat sebanyak 24 pasien kanker nasofaring per tahun per 100.000 penduduk, sedangkan angka rata rata di Cina bagian selatan berkisar antara 20 per 100.000 penduduk, dibandingkan dengan negara Eropa atau Amerika Utara yang 
mempunyai angka kejadian hanya 1 per 100.000 penduduk per tahun. Angka kejadian KNF di Indonesia cukup tinggi, yaitu sekitar 4,7 kasus baru per tahun per 100.000 penduduk atau diperkirakan sekitar 7000 - 8000 kasus per tahun di seluruh Indonesi. Indonesia, menempati urutan ke-4 diantara keganasan yang terdapat di seluruh tubuh. Santosa (1988) mendapatkan jumlah $716(8,46 \%)$ penderita KNF berdasarkan data patologi yang diperoleh di Laboratorium Patologi anatomi FK Unair Surabaya (1973 - 1976) diantara 8463 kasus keganasan di Seluruh tubuh.

Studi di Taiwan menyatakan bahwa risiko KNF meningkat pada paparan debu kayu $>10$ tahun dan perokok sigaret $\geq 25$ tahun. Nitrosamin yang ter-kandung pada asinan dan ikan asin, merupakan karsinogenik kimiawi paling kuat, dapat mengaktifkan EBV dan menimbulkan KNF. Paparan formaldehyde melalui metabolisme oleh enzim - enzim tubuh diubah menjadi ultimate -carcinogen yang bersifat reaktif dalam ikatan dengan DNA, menyebabkan mutasi genetik yang menimbulkan KNF. Studi lain membuktikan adanya peningkatan risiko terjadinya KNF pada individu yang memakan ikan asin pada anak <2 tahun $(\mathrm{OR}=3,8)$, dan konsumsi alkohol $>15$ gelas/minggu dapat meningkatkan risiko kejadian KNF.

Nasofaring terletak pada saluran nafas bagian atas di belakang kavum nasi berbentuk kerucut terpotong. Daerah tetangga nasofaring adalah rongga hidung, tuba eustakius dan basis krani. Pertumbuhan tumor pada daerah tetangga menimbulkan manifestasi klinik tertentu. Dalam pertumbuhan KNF dikenal bentuk yaitu bentuk ulkus, nodul, dan eksofitik. (Gani Tambunan, 1995)

Gejala dan tanda pada kanker nasofaring tidak spesifik, sering sekali penderita mengalami salah diagnosis atau berobat ke dokter dalam kondisi stadium lanjut, sehingga terapi menjadi lebih rumit. Selain radioterapi sebagai pilihan utama terapi KNF stadium dini, maka diperlukan juga kemoterapi dan kadang kala operasi pada KNF stadium lanjut, sehingga biaya semakin mahal dan kadang hasil pengobatan tidak memuaskan.

\section{METODE PENELITIAN}

Metode yang digunakan dalam studi kasus ini adalah metode deskriptif dengan pemaparan kasus dan menggunakan pendekatan proses keperawatan dengan memfokuskan pada salah satu masalah penting dalam kasus yang dipilih yaitu asuhan keperawatan medikal bedah mengenai penatalaksanaan terapi nonfarmakologis pada klien dengan kanker nasofaring yang dilakukan pada satu responden. Studi kasus ini dilakukan di Bangsal Bedah RSUD Tidar Kota Magelang mulai 8 Juli 2018 - 9 Juli 2018.

Instrumen yang digunakan dalam kegiatan penelitian adalah Format Asuhan Keperawatan Medikal Bedah.

\section{HASIL DAN PEMBAHASAN}

\section{a. Pengkajian}

Pengkajian Tn. K dilakukan pada tanggal 8 Juli 2018. Tn. K mengatakan nyeri bagian antara leher dan pipinya yang dirasakan sejak 1 tahun yang lalu, nyeri hilang timbul, nyeri yang dirasakan seperti ditusuk jarum.

Klien Klien terlihat meringis menahan nyeri. Skala nyeri 6 dari skala 0-10 yang diberikan.

Tanda - tanda vital yang didapat nadi : $80 \times$ per menit, suhu : $36,5^{\circ} \mathrm{C}$, pernapasan : $20 \times$ per menit, tekanan darah : $130 / 80 \mathrm{mmHg}$

\section{b. Diagnosa Keperawatan}

Rumusan prioritas diagnosa untuk Tn. K adalah Nyeri Kronis berhubungan dengan pembengkakan jaringan

\section{c. Intervensi Keperawatan}

Rencana keperawatan untuk mengatasi masalah $\mathrm{Tn}$. $\mathrm{K}$ yaitu:

- Kaji skala nyeri secara komprehensif

- Minimalkan aktivitas klien

- Ukur tanda - tanda vital

- Ajarkan pada klien teknik relaksasi dan distraksi latihan nafas dalam

- Kolaboratif dalam pemberian analgetik

\section{d. Implementasi Keperawatan}

Tindakan keperawatan yang dilakukan pada $\mathrm{Tn}$. $\mathrm{K}$ selama 2 hari perawatan berturut - turut di rumah sakit yaitu:

Hari ke-1

Pada hari pertama dilakukan tindakan keperawatan yaitu :

- Mengkaji skala nyeri secara komprehensif

- Meminimalkan aktivitas klien

- Mengukur tanda - tanda vital

- Mengkolaborasi dalam pemberian analgetik

Hari ke-2

Pada hari kedua dilakukan tindakan keperawatan yaitu :

- Mengkaji skala nyeri secara komprehensif

- Meminimalkan aktivitas klien

- Mengukur tanda - tanda vital

- Mengajarkan pada klien teknik relaksasi dan distraksi latihan nafas dalam 
- Mengkolaborasi dalam pemberian analgetik

e. Evaluasi Keperawatan

Evaluasi keperawatan pada Tn. K adalah sebagai berikut:

$S$ : Klien mengatakan nyeri berkurang pada bagian antara leher dan pipinya yang dirasakan sejak 1 tahun yang lalu, nyeri hilang timbul, nyeri yang dirasakan seperti ditusuk jarum

0 : Klien tampak tenang, skala nyeri 4 dari skala 0-10 yang diberikan. nadi : $80 \mathrm{x}$ per menit, suhu : $36,4^{\circ} \mathrm{C}$, pernapasan : $20 \times$ per menit, tekanan darah : 120/80 $\mathrm{mmHg}$

A : Masalah teratasi sebagian

$P$ : lanjutkan intervensi

- kaji nyeri secara komprehensif

- kolaborasi pemberian obat analgetik

\section{PEMBAHASAN}

\section{a. Pengkajian}

Pengkajian yang penulis lakukan pada Tn. K pada tanggal 8 Juli 2018 diperoleh data bahwa keluhan utama pada klien dengan kanker nasofaring adalah nyeri antara leher dan pipi yang dirasakan sejak 1 tahun yang lalu, nyeri hilang timbul, nyeri yang dirasakan seperti ditusuk jarum. nadi : $80 \times$ per menit, suhu : $36,5^{\circ} \mathrm{c}$, pernapasan : $20 \times$ per menit, tekanan darah : $130 / 80 \mathrm{mmHg}$

\section{b. Perumusan masalah}

Berdasarkan data fokus dalam pengkajian maka permasalahan / diagnosis keperawatan berdasarkan NANDA (2015) pada Tn. K adalah Nyeri Kronis akibat pembengkakan jaringan yang sudah dirasakan sejak 1 tahun yang lalu, karena adanya nyeri yang dirasakan sehingga terjadi perubahan nutrisi: kurang dari kebutuhan tubuh karena klien mengeluh tidak nafsu makan dan susah menelan disertai mual.

Kerusakan integritas kulit akibat efek dari radioterapi ditandai dengan kulit dibagian leher terasa kering dan kusam, kulit berwarna hitam dan kering dan dengan luka. Harga Diri Rendah karena klien merasa tidak percaya diri/malu terhadap penampilannya karena efek dari radioterapi

Alasan penulis menegakkan diagnosa nyeri karena pada saat dilakukan pengkajian, klien mengeluh nyeri antara leher dan pipinya yang dirasakan sejak 1 tahun yang lalu, nyeri hilang timbul, nyeri yang dirasakan seperti ditusuk jarum, skala nyeri 6 dari skala 0 10 yang diberikan.

Penulis memperioritaskan diagnosa nyeri karena jika tidak segera ditangani maka nyeri yang dirasakan akan mempengaruhi penyembuhan dan nutrisi yang masuk akan semakin sedikit karena merasa nyeri saat menelanya.

\section{c. Perencanaan Keperawatan}

Dalam membuat

sebuah perencanaan untuk mengatasi masalah nyeri antara lain : mengkaji skala nyeri secara komprehensif untuk mengetahui penyebab nyeri yang dirasakan, daerah nyeri, bagaimana nyeri yang terasa mungkin seperti ditusuk - tusuk, skala nyeri menggunakan standar skala nyeri skala Wong Baker FACES maupun skala penilainan numerik, dan mengetahui seberapa sering nyeri dirasakan oleh klien. Meminimalkan aktivitas klien untuk meminimalkan klien beraktifitas yang bisa menyebabkan nyeri timbul atau bisa memperparah nyeri yang dirasakan. Mengukur tanda - tanda vital meliputi tekanan darah, nadi, suhu, dan respiratory rate $(\mathrm{RR})$ untuk memastiakan keadaan klien dalam kondisi normal dan tidak ada peningkatan tekanan darah dan nadi akibat rasa nyeri yang dirasakan klien. Mengajarkan pada klien teknik relaksasi dan distraksi latihan nafas dalam untuk membantu klien melakukan relaksasi nafas dalam untuk mengurangi nyeri yang timbul dan distraksi atau pengalin perhatian seperti mengajak ngobrol sehingga rasa nyeri klien dapat teralihkan. Mengkolaborasi dalam pemberian analgetik untuk mengurasi rasa nyeri secara lebih cepat dengan berkolaborasi dengan dokter.

d. Implementasi Keperawatan

Pada diagnosa ini kekuatan dari intervensinya adalah nyeri yang dirasakan pada $\mathrm{Tn}$. $\mathrm{K}$ dapat berkurang dengan menggunakan teknik penatalaksanaan nyeri. Pada hari pertama pengkajian didapatkan diagnosa keperawatan nyeri berhubungan dengan agen cedera fisik dan dilakukan tindakan keperawatan yaitu mengkaji skala nyeri secara komprehensif dan didapatkan hasil klien mengeluh nyeri antara leher dan pipinya yang dirasakan sejak 1 tahun yang lalu, nyeri hilang timbul, nyeri yang dirasakan seperti ditusuk jarum, skala nyeri 6 dari skala 010 yang diberikan. Meminimalkan aktivitas klien untuk mengurangi rasa nyeri yang timbul atau dirasakan oleh klien. Mengukur tanda - tanda vital dan didapatkan hasil nadi : $80 \times$ per menit, suhu : $36,5^{\circ} \mathrm{C}$, pernapasan : $20 \times$ per 
menit, tekanan darah : 130/80 mmHg. Mengkolaborasi dalam pemberian analgetik dengan dokter untuk mengurangi nyeri secara cepat.

pada hari kedua dilakukan tindakan keperawatan yaitu mengkaji kembali skala nyeri secara komprehensif dan didapatkan hasil klien mengeluh masih merasakan nyeri antara leher dan pipinya, nyeri hilang timbul, nyeri yang dirasakan seperti ditusuk jarum, skala nyeri 4 dari skala 0-10 yang diberikan.

Meminimalkan aktivitas klien untuk mengurangi rasa nyeri yang timbul atau dirasakan oleh klien. Mengukur tanda tanda vital dan didapatkan hasil nadi : 80 $x$ per menit, suhu : $36,5^{\circ} \mathrm{C}$, pernapasan : $20 \times$ per menit, tekanan darah : 120/80 $\mathrm{mmHg}$. Mengkolaborasi dalam pemberian analgetik dengan dokter untuk mengurangi nyeri secara cepat.

\section{e. Evaluasi}

Evaluasi keperawatan dilakukan pada tanggal 8 - 9 Juli 2018, dengan diagnosa keperawatan nyeri kronis berhubungan dengan pembengkakan jaringan. Pada tanggal 8 Juli 2018 setelah dilakukan tindakan keperawatan yang sesuai dengan rencana keperawatan didapatkan hasil yaitu Klien mengatakan nyeri berkurang pada bagian antara leher dan pipinya yang dirasakan sejak 1 tahun yang lalu, nyeri hilang timbul, nyeri yang dirasakan seperti ditusuk jarum. Klien tampak lebih tenang, skala nyeri 5 dari skala 0-10 yang diberikan. nadi : $80 \times$ per menit, suhu : $36,4^{\circ} \mathrm{C}$, pernapasan : $20 \mathrm{x}$ per menit, tekanan darah : 130/80 mmHg. Rencana keperawatan akan dilanjutkan dengan mengkaji nyeri secara komprehensif dan mengkolaborasi pemberian obat analgetik.

Pada tanggal 9 Juli 2018 setelah dilakukan tindakan keperawatan yang sesuai dengan rencana keperawatan didapatkan hasil yaitu Klien mengatakan nyeri berkurang pada bagian antara leher dan pipinya yang dirasakan sejak 1 tahun yang lalu, nyeri hilang timbul, nyeri yang dirasakan seperti ditusuk jarum. Klien tampak tenang, skala nyeri 4 dari skala 0 10 yang diberikan. nadi : $80 \times$ per menit, suhu : $36,4^{\circ} \mathrm{C}$, pernapasan : $20 \mathrm{x}$ per menit, tekanan darah : 120/80 mmHg. Rencana keperawatan akan dilanjutkan dengan mengkaji nyeri secara komprehensif dan mengkolaborasi pemberian obat analgetik.

Nyeri yang dirasakan klien sudah berkurang karena saat dikaji klien sudah hari ke 3 berada di bangsal. Sehingga penulis perlu mempertahankan untuk implementasi berupa: mengkaji skala nyeri secara komprehensif, meminimalkan aktivitas klien, mengukur tanda - tanda vital, mengajarkan pada klien teknik relaksasi dan distraksi latihan nafas dalam dan mengkolaborasi dalam pemberian analgetik.

\section{KESIMPULAN}

Dalam melakukan asuhan keperawatan Tn. K dengan kanker nasofaring di RSUD Tidar Kota Magelang penulis menggunakan tahap proses keperawatan yaitu: pengkajian, diagnosa keperawatan, intervensi keperawatan, implementasi keperawatan dan evaluasi

Berdasarkan hasil pengkajian Tn. K mengalami kanker nasofaring, klien mengeluh nyeri antara leher dan pipinya yang dirasakan sejak 1 tahun yang lalu, nyeri hilang timbul, nyeri yang dirasakan seperti ditusuk jarum, skala nyeri 6 dari skala $0-10$ yang diberikan. Prioritas diagnosa yang diambil adalah nyeri kronis berhubungan dengan pembengkakan jaringan.

Intervensi yang disusun untuk penatalaksanaan nyeri pada $\mathrm{Tn}$. $\mathrm{K}$ di fokuskan pada penggunaan terapi nonfarmakologis untuk mengurangi rasa nyeri meskipun tetap diberikan terapi farmakologi yaitu kaji skala nyeri secara komprehensif, minimalkan aktivitas klien, ukur tanda - tanda vital, ajarkan pada klien teknik relaksasi dan distraksi latihan nafas dalam, kolaborasi dalam pemberian analgetik dengan dokter

Implementasi dilaksanakan selama 2 hari berturut - turut (8 - 9 Juli 2018) berdasarkan keluhan klien dan data yang ada sesuai dengan intervensi yang sudah dibuat yaitu mengkaji skala nyeri secara komprehensif, meminimalkan aktivitas klien, mengukur tanda - tanda vital, mengajarkan pada klien teknik relaksasi dan distraksi latihan nafas dalam, mengkolaborasi dalam pemberian analgetik

Evaluasi yang dialakukan adalah evaluasi kerja dan evaluasi hasil dari tindakan keperawatan yang telah dilakukan selama dua hari secara berturut - turut yaitu Klien mengatakan nyeri berkurang pada bagian antara leher dan pipinya yang dirasakan sejak 1 tahun yang lalu, nyeri hilang timbul, nyeri yang dirasakan seperti ditusuk jarum. Klien tampak tenang, skala nyeri dari 6 menjadi 4 dari skala 0-10 yang diberikan. nadi : $80 \mathrm{x}$ per menit, suhu : $36,4^{\circ} \mathrm{C}$, pernapasan : $20 \times$ per menit, tekanan darah : dari $130 / 80 \mathrm{mmHg}$ menjadi $120 / 80 \mathrm{mmHg}$. 


\section{SARAN}

Perawat dalam melakukan asuhan keperawatan hendaknya menggunakan pendekatan proses keperawatan secara komperhensif dengan melibatkan peran serta

\section{DAFTAR PUSTAKA}

Bulecheck, M. dkk. 2016. Nursing Intervention Classivication (NIC). Singapore: ELSEVIER

Damayanti, B S., Afiati., Hasan A A., \& Hernowo B S. 2015. Imunoekspresi Bcl-2 sebagai Prediktor Respons Radioterapi pada Karsinoma Nasofaring yang Tidak Berdiferensiasi. Journal of Medicine and Health Vol 1 (1): Hal 1-11

Hasibuan, S. 2011. Komplikasi Oral Pada Klien yang Menjalani Radioterapi Kanker Nasofaring Di RSUP H. Adam Malik Medan. USU Institutional Repository

Johnson, Marion. dkk. 2016. Nursing Outcomes Clasivication (NOC). Singapore: ELSEVIER

Kamitsuru, Shigemi. dkk. 2015. Diagnosis Keperawatan Klasifikasi dan Devinisi Edisi 10. Jakarta: EGC

Kartini, Mardiana \& Widjasena, Apoina Baju. 2012. Tingkat ketahanan hidup penderita kanker Nasofaring pada berbagai modalitas terapi: studi kasus yang menjalani terapi konvensional dan pengobatan komplementer alternatif. Media Medika Indonesia aktif pasien sebagai asuhan keperawatan sehingga dapat mencapai sesuai tujuan.

Memberikan pelayanan sesuai standar oprasional praktik keperawatan dalam memberikan asuhan keperawatan pada pasien kanker nasofaring.

Nasir, A., \& Muhith, A. 2011. Dasar-Dasar Keperawatan Jiwa: Pengantar dan Teori. Jakarta: Salemba Medika

Sufiawati, Irna \& Subita, Gus Permana. 2013. Identifikasi dan Pengendalian Faktor Risiko Mukositis Oral Selama Radioterapi Kanker Nasofaring. Journal of Dentistry Indonesia

Tambunan, Gani \& Handojo Maylani. 1995. Diagnosis dan Tatalaksana Sepuluh Jenis Kanker Terbanyak di Indonesia. Jakarta: EGC

Widodo Ario, Kentjono. 2003. Perkembangan Terkini Penatalaksanaan Karsinoma Nasofaring. Majalah Kedoteran Tropis Indonesia 